UDC $341.1 / 8$

LBC 67.91

\title{
POSSIBILITIES AND LIMITS OF THE SAFEGUARDING OF INTANGIBLE CULTURAL HERITAGE WITH THE INTERNATIONAL SYSTEM OF HUMAN RIGHTS PROTECTION
}

\author{
Gunay Vidadi qizi Aliyeva \\ Peoples' Friendship University of Russia, Moscow, Russian Federation
}

Introduction: the article is devoted to the possibilities of the international system of human rights protection in the safeguarding of intangible cultural heritage. The author aims to explore the limits of the international system of human rights protection in the absence of direct reference to the safeguarding of intangible cultural heritage in the international human rights instruments. Methods: the methodological framework for the study was general scientific (the method of logical and system analysis, dialectical method) and specific scientific (the formal legal method, the method of legal modeling and forecasting) methods of cognition. Results: the article investigates the problems of a conceptual nature that arise when using the human rights mechanisms in the safeguarding of intangible cultural heritage, and suggests the ways of overcoming them. Conclusions: even in the absence of explicit reference to the safeguarding of intangible cultural heritage in the international human rights instruments of a universal and regional character, the international system for the protection of human rights is considered to be an effective means of protecting the cultural rights and, consequently, the cultural identity, which is the basis of intangible cultural heritage.

Key words: cultural heritage, world heritage, intangible cultural heritage, international legal regime for the safeguarding of intangible cultural heritage, human rights, cultural rights, international system for the protection of human rights.

Citation. Aliyeva Gunay Vidadi qizi. Possibilities and Limits of the Safeguarding of Intangible Cultural Heritage with the International System of Human Rights Protection. Legal Concept, 2018, vol. 17, no. 3, pp. 133-145. DOI: https://doi.org/10.15688/lc.jvolsu.2018.3.19

УДК $341.1 / 8$

ББК 67.91

\section{ВОЗМОЖНОСТИ И ПРЕДЕЛЫ ОХРАНЫ НЕМАТЕРИАЛЬНОГО КУЛЬТУРНОГО НАСЛЕДИЯ С ПОМОЩЬЮ МЕЖДУНАРОДНОЙ СИСТЕМЫ ЗАЩИТЫ ПРАВ ЧЕЛОВЕКА}

Гюнай Видади кызы Алиева

Российский университет дружбы народов, г. Москва, Российская Федерация

Введение: статья посвящена рассмотрению возможностей международной системы защиты прав человека в деле охраны нематериального культурного наследия. Автором поставлена цель исследовать пределы международной системы защиты прав человека в условиях отсутствия прямого указания на охрану нематериального культурного наследия в международно-правовых актах о правах человека. Методы: методологическую основу исследования составили общенаучные (метод логического и системного анализа, диалектический метод) и частнонаучные (формально-юридический, метод правового моделирования и прогнозирования) методы познания. Результаты: в статье исследованы проблемы концептуального характера, которые возникают при использовании правозащитных механизмов в деле охраны нематериального культурного наследия, предложены пути их преодоления. Выводы: даже в условиях отсутствия прямого указания на охрану нематериального культурного наследия 
в международно-правовых актах о правах человека универсального и регионального характера, международная система защиты прав человека считается одним из действенных средств охраны культурных прав и, следовательно, культурной самобытности, являющейся основой нематериального культурного наследия.

Ключевые слова: культурное наследие, всемирное наследие, нематериальное культурное наследие, международно-правовой режим охраны нематериального культурного наследия, права человека, культурные права, международная система защиты прав человека.

Цитирование. Алиева Гюнай Видади кызы. Возможности и пределы охраны нематериального культурного наследия с помощью международной системы защиты прав человека // Legal Concept = Правовая парадигма. - 2018. - Т. 17, № 3. - C. 133-145. - DOI: https://doi.org/10.15688/lc.jvolsu.2018.3.19

\section{Введение}

Осознание международным сообществом (представляющим собой своего рода совокупность многокультурных государств [30, p. 147169] или «многокультурный мир» [8]) необходимости признания, поощрения и защиты культурного многообразия в качестве одной из основ его гармоничного развития и поддержания мира на национальном и глобальном уровнях является характерной чертой нынешнего этапа развития межгосударственных отношений, регулируемых современным международным правом. В соответствии с Конвенцией ЮНЕСКО об охране нематериального культурного наследия 2003 г., под «нематериальным культурным наследием» (далее - НКН) понимаются «обычаи, формы представления и выражения, знания и навыки, - а также связанные с ними инструменты, предметы, артефакты и культурные пространства, - признанные сообществами, группами и, в некоторых случаях, отдельными лицами в качестве части их культурного наследия» [13]. Благодаря такому осознанию охрана НКН на международно-правовом уровне осуществляется от имени всего человечества, то есть на самом высоком уровне, а цель этой охраны - объект, находящийся на локальном уровне, - культурная самобытность сообществ и лиц, принадлежащих к этим сообществам. Наблюдается тенденция, сочетающая в себе противоположные стремления: в условиях глобализации связи между различными культурами становятся тесными, но при этом усиливается и стремление сообществ к сохранению своей самобытности.

Очевидно, что когда речь идет о международно-правовой охране НКН, имеющего прямое отношение к культурной самобытности сообществ и лиц, принадлежащих к этим сообществам, дискуссия автоматически переносится на международную систему защиты прав человека в целом, на возможности и пределы применения этой системы для охраны НКН, включая вопрос о совместимости при охране НКН его коллективных и индивидуальных аспектов, который часто возникает при международно-правовой защите прав национальных/этнических, религиозных, языковых меньшинств и коренных народов.

По мнению одного из договорных органов по правам человека системы $\mathrm{OOH}$, защиту культурного разнообразия следует считать этическим императивом, она неотделима от уважения достоинства человеческой личности, подразумевающего обязательство уважать права человека и необходимость полного осуществления культурных прав, включая право на участие в культурной жизни [8].

Таким образом, рассмотрение возможности охраны НКН с помощью международной системы защиты прав человека предполагает восприятие культурной самобытности в качестве одной из составных частей этой системы защиты независимо от того обстоятельства, что существующие международные договоры по правам человека четко и прямо не фиксируют такую защиту. При такой постановке вопроса, во-первых, расширяется сфера охвата системы защиты прав человека за счет охвата сферы несоциальной среды, частью которой является НКН; во-вторых, существующие международно-правовые принципы и нормы по защите прав человека подлежат исследованию через призму их способности защищать специфические особенности, которые характерны отношениям между сообществом (включая лиц, принадлежащих к нему) и его образом жизни. Из сказанного следует, что защищая права человека, связанные с культурой самобытности, можно потен- 
циально охранять и НКН. Именно данная привязка определяет взаимосвязь между защитой прав человека и охраной культурной самобытности. Такая взаимосвязь, в свою очередь, диктует необходимость исследования международно-правовых основ и механизмов защиты прав человека, которые могут быть использованы для охраны одного из ключевых элементов НКН - культурной самобытности. В этом контексте следует в обязательном порядке иметь в виду одно обстоятельство: поскольку международная система защиты прав человека допускает правомерные ограничения, можно и нужно ожидать подобные ограничения и при охране НКН с помощью этой системы.

\section{Доктринальные подходы к вопросу}

\section{о распространении действия}

международной системы

защиты прав человека на охрану

\section{нематериального культурного наследия}

На фоне сказанного не представляет трудности определение методологии дальнейшего исследования: следует ответить на вопрос о том, каким образом права человека являются возможным основанием для охраны НКН, и затем проверить, в какой степени существующая международная система защиты прав человека способна обеспечить охрану культурной самобытности в условиях, когда эта система специально не создана для этой цели.

В работах специалистов (преимущественно зарубежных) охрана самобытности в целом упоминается в качестве обоснования для охраны НКН [38], а охрана культурной самобытности рассматривается в качестве цели осуществления прав человека в той мере, в которой самобытность имеет человеческое измерение, прежде всего, в части обеспечения человеческого достоинства [37, p. 178-202], являющегося базовым концептуальным элементом международной системы защиты прав человека. В ст. 1 Всеобщей декларации прав человека это положение зафиксировано так: «Все люди рождаются свободными и равными в своем достоинстве и правах...» [3].

Человеческое измерение заложено и в основе Конвенции ЮНЕСКО об охране нематериального культурного наследия 2003 г. [13].
Комментируя положения данной Конвенции, профессор Дж. Блейк утверждает, что использование в Конвенции термина «охрана» подразумевает институт защиты прав человека [20, p. 35]. Из такого утверждения вытекает, что охрана культурной самобытности адекватна защите прав на культурную самобытность и защите составляющих элементов культуры.

Для укрепления тезиса о взаимосвязи между НКН и правами человека в условиях отсутствия доказательств в виде позитивного международного права прав человека, востребованным становится учет практики защиты меньшинств, система которой действовала в рамках Лиги Наций [1, с. 35-80], однако затем была заменена в рамках $\mathrm{OOH}$ индивидуальным подходом к защите прав лиц, принадлежащих к меньшинствам [34], что нашло отражение в ст. 27 Международного пакта о гражданских и политических правах 1966 г. и Декларации о правах лиц, принадлежащих к национальным или этническим, религиозным и языковым меньшинствам 1992 г. [17, с. 273278]. Статья 27 Пакта гласит: «В тех странах, где существуют этнические, религиозные и языковые меньшинства, лицам, принадлежащим к таким меньшинствам, не может быть отказано в праве совместно с другими членами той же группы пользоваться своей культурой, исповедовать свою религию и исполнять ее обряды, а также пользоваться родным языком» [16].

С целью получения ответов на поставленные выше вопросы следует прежде всего изучить основания доктринального уровня по возражению в отношении использования международной системы защиты прав человека для охраны НКН. Эти основания для возражений кроются преимущественно в характере НКН, а также связаны с пределом международной системы защиты прав человека.

Наверное, мало кто из специалистов сомневаются в том, что права человека могут служить одним из средств охраны НКН, однако их мнения заметно расходятся по поводу значения международной системы защиты прав человека для охраны НКН.

Что касается предела международной системы защиты прав человека для охраны НКН, то специалисты отмечают две черты этой системы. Во-первых, обращается внимание на то, что при включении охраны культурного насле- 


\section{МЕЖДУНАРОДНОЕ ПРАВО И СРАВНИТЕЛЬНОЕ ПРАВОВЕДЕНИЕ}

дия в деятельность правозащитных механизмов (как на универсальном, так и на внутригосударственном уровнях) расширяются пределы самой системы защиты прав человека за счет охвата тех новых прав человека, которые изначально не включались в эту систему, прежде всего - так называемое третье поколение прав человека. Это достигается, в частности, путем применения «эволюционного толкования» существующих положений Европейской конвенции о защитеправ человека и основных свобод 1950 г., и оно уже применяется в деятельности Европейского суда по правам человека (ЕСПЧ) посредством широкого толкования, например, права на уважение частной и семейной жизни, закрепленного в ст. 8 Европейкой конвенции о защите прав человека и основных свобод 1950 г. $[9 ; 32]$. Таким же путем договорными органами по правам человека системы ООН достигается уточнение некоторых элементов социальных прав человека (право на воду, право на питание), прямо не закрепленных в международных договорах по правам человека, или же предпринимаются попытки обосновать существование таких прав, как «сексуальные», которые не существуют в природе. Во-вторых, вопрос о пределах международной системы защиты прав человека непосредственно связан с проблемой о возможности сочетания защиты коллективных и индивидуальных прав человека. Сама Конвенция ЮНЕСКО 2003 г. отдает предпочтение коллективным интересам сообщества путем рассмотрения ею НКН в виде обычаев, «связанных с сообществами, группами и, в некоторых случаях, отдельными лицами в качестве части их культурного наследия». Упоминание в цитируемом положении об отдельных лицах «в некоторых случаях» является подтверждением позиции Конвенции о предпочтении учета коллективных интересов.

\section{Обоснования}

нормативно-концептуального характера возможностей и пределов международной системы

защиты прав человека в деле охраны нематериального культурного наследия

Нынешняя международная правозащитная система по рассмотрению сообщений (жа- лоб) целиком ориентирована на обеспечение индивидуальных прав и свобод человека. Подтверждением является деятельность региональных систем защиты прав человека, прежде всего Европейской и Межамериканской систем, и договорных органов по правам человека системы ООН. Эти органы не рассчитаны на защиту больших групп (actio pipularis). Хотя вопрос о защите коллективных прав нередко возникает в деятельности региональных правозащитных органов, однако он затрагивается ими лишь в той степени, в которой для решения отдельного случая необходимо принимать меры, оказывающие воздействие на сообщество в целом, и способные принести пользу индивидам-жертвам по аналогичным ситуациям нарушений прав человека. В деятельности Межамериканского суда по правам человека, например, это проявляется преимущественно в определении ущерба, подлежащего возмещению [26].

На первый взгляд, в этом подходе в пользу предпочтения защиты индивидуальных прав человека не вписываются тождественные положения о праве на самоопределение, закрепленные в статьях 1 обоих Международных пактов о правах человека 1966 г., гласящих: «Все народы имеют право на самоопределение. В силу этого права они свободно устанавливают свой политический статус и свободно обеспечивают свое экономическое, социальное и культурное развитие». Согласно п. 2 данной статьи, «все народы для достижения своих целей могут свободно распоряжаться своими естественными богатствами и ресурсами...» [18].

Комитет по правам человека, осуществляющий международный контроль за выполнением государствами-участниками обязательств по Международному пакту о гражданских и политических правах и обладающий компетенцией на основе Факультативного протокола к Пакту [18] получать и рассматривать индивидуальные сообщения (жалобы) о нарушении соответствующим государствомучастником прав, закрепленных в Пакте, не раз отклонял жалобы на том основании, что ст. 1 Пакта о самоопределении не касается индивидуальных жалоб или же Комитет привязывал жалобу к нарушению прав человека по другим статьям Пакта. Примером после- 
днего может служить дело о рыболовстве народности Маури [25].

Комитет по правам человека в своем Замечании общего порядка № 12 по ст. 1 Пакта (право на самоопределение), принятом в 1984 г. [6], заявил, что реализация права на самоопределение «является важнейшим условием для эффективной гарантии и соблюдения прав человека отдельных лиц, а также для расширения и укрепления этих прав». В этом контексте уместно процитировать и мнение этого же Комитета, содержащееся в его Замечании общего порядка № 23 по ст. 27 Пакта, согласно которому данная статья (процитированная нами выше) «устанавливает и признает за лицами, принадлежащими к меньшинствам, право, которое является ясно различным и предоставляется в дополнение ко всем другим правам, которыми эти лица вместе со всеми другими членами общества уже пользуются в соответствии с Пактом» [7].

Право на самоопределение, как считает Комитет, не относится к числу прав, закрепленных в Факультативном протоколе, а ст. 27, которая касается прав индивидов как таковых, наоборот, подпадает под действие Факультативного протокола. Сказанное означает, что ст. 1 Пакта не предполагает подачи индивидуальных жалоб на нарушение права на самоопределение как таковое.

Комитет разъясняет, что тот или иной аспект прав лиц, защищаемых в соответствии со ст. 27 Пакта, в отношении пользования какой-либо конкретной культурой может предполагать образ жизни, тесно связанный с территорией и использованием ее ресурсов. Это, по мнению Комитета, особенно касается членов общин коренных народов, составляющих меньшинство.

Комитет далее констатирует: «Из формулировки ст. 27 следует, что к числу лиц, имеющих право на защиту, относятся лица, принадлежащиек той или иной группе и пользующиеся общей культурой, религией и/или языком». При этом Комитет замечает: хотя права, закрепленные в ст. 27 , являются правами личности, они в свою очередь зависят от способности группы, относящейся к числу меньшинств, сохранять свою культуру, язык или религию. Соответственно эффективные меры со стороны государств могут быть необходи- мы для сохранения самобытности какоголибо меньшинства и прав его членов пользоваться своей культурой и языком и развивать их, а также исповедовать свою религию совместно с другими членами группы.

Касаясь культуры в контексте ст. 27, Комитет отмечает, что она проявляется во многих формах, включая образ жизни, связанный с использованием земельных ресурсов, особенно в случае коренных народов. Право на культуру, по мнению Комитета, может включать такие традиционные виды деятельности, как рыболовство или охота, а также право жить в резервациях, охраняемых законом.

В конце Замечания общего порядка № 23 Комитет отмечает, что ст. 27 имеет отношение к правам, защита которых налагает конкретные обязательства на государства участники Пакта. Защита этих прав направлена на обеспечение сохранения и непрерывного развития культурной самобытности соответствующих меньшинств, обогащая тем самым ткань общества в целом.

Затрагивая вопрос о защите индивидуальных и коллективных прав в связке с охраной НКН и в контексте международной системы защиты прав человека, мы попадаем на поле либерального подхода к защите прав человека и основных свобод, основанного на поощрении и уважении индивидуальных прав, где групповые интересы сводятся к интересам отдельных лиц. В правовой доктрине есть мнение о том, что объединение групповых и индивидуальных прав ослабляет сложную структуру социальных отношений и сводит их к простой структуре отдельных ее компонентов. Есть мнения и о том, что групповые права не могут быть обеспечены через защиту прав отдельных лиц [27, p. 180], и о том, что некоторые индивидуальные права не могут быть осуществлены вообще без обеспечения групповых прав [22, p. 115].

На фоне противоположных подходов [24, p. 293] по рассматриваемой теме следует констатировать, что через групповые права действительно могут коллективно измеряться права отдельных лиц [28, p. 629], что позволяет избежать необходимости создания «новых» категорий индивидуальных прав человека.

Опыт системы защиты меньшинств Лиги Наций подтверждает, что защита груп- 
повых прав не устраняет возможные столкновения между интересами групп и противоположными интересами отдельных лиц, принадлежащих к таким группам. Именно этим объясняется тот факт, что система защиты меньшинств, действовавшая в рамках Лиги Наций и основанная на международных договорах различного уровня о защите прав меньшинств, пользовалась терминологией индивидуальных прав. Аналогичное объяснение имеет предпочтение правозащитной системы OOH к обеспечению групповых прав с помощью системы обеспечения индивидуальных прав. В рамках Совета Европы этот подход применительно к защите прав меньшинств был подтвержден принятием Европейской хартии региональных языков или языков меньшинств [5].

На доктринальном уровне существует мнение о том, что защита меньшинств может привести к такому пониманию, когда интересы отдельных лиц будут умалены в пользу определенного представления о потребностях групп. Согласно такому мнению, поскольку интересы группы и отдельных лиц не должны преобладать над интересами отдельных лиц, защита прав отдельных лиц является условием защиты групп [29, р. 137]. Это мнение не разделяется другими специалистами по той причине, что оно не признает за сообществами права на самосохранение. При этом ими подчеркивается, что столкновения между индивидуальными и групповыми правами на деле являются столкновениями между правами отдельных лиц как членов сообщества с культурной точки зрения, с одной стороны, и прав отдельных лиц как части целого политического сообщества - с другой [31, p. 150].

В последнее время все чаще проявляет себя еще один подход в доктрине, на основе которого проблемы индивида изучаются в контексте проверки того, как связь индивида с группой формирует его личность. В связи с этим специалистами вводится понятие «социально расположенного человека» взамен индивида [23, p. 141].

В этой дискуссии важным является учет того факта, на который обращают внимание ученые, комментируя положения Конвенции ЮНЕСКО 2003 г., а именно то, что наряду с акцентом на коллективные культурные права
Конвенция также говорит об универсальных стандартах в области прав человека, которые основаны на концепции обеспечения индивидуальных прав человека [20, p. 35].

Такой подход подкрепляется еще одной точкой зрения, которая выравнивает напряженность между правами индивидов и групп посредством обеспечения интересов, которые должны быть защищены наследием. По мнению его сторонников, взглянуть на наследие с точки зрения интересов групп означает поддерживать прежде всего национальные интересы, которые не всегда могут защищать наследие [23, p. 3]. Согласно еще одному мнению, изучение наследия с точки зрения индивидуальных прав открывает возможность рассматривать его как «общее наследие человечества», которое придает ему космополитический характер и повышает целесообразность защиты именно потому, что оно становится частью личности каждого, в настоящем и будущем, а также самобытности определенной группы [33, p. 52]. На наш взгляд, именно этот подход был воспринят Конвенцией ЮНЕСКО, так как индивидуализм является ключом к построению концепции «общего наследия человечества», которая оправдывает интернационализм в области культурного наследия. Но Конвенция также отходит от отсылки к отдельным лицам, обращаясь к ним во вторую очередь после «сообществ».

Аргумент, основанный на справедливости в отношениях между поколениями в качестве еще одного обоснования для охраны культурного наследия (то есть идея о том, что наследие должно охраняться в интересах будущих поколений), является доводом в пользу точки зрения, ориентированной на группы [28, p. 635]. Взаимосвязь и преемственность между поколениями становятся важными факторами охраны культурного наследия в целом и нематериального культурного наследия в частности. Одной из основных характерных черт культурного наследия как «общей заботы человечества» является идея о том, что будущие поколения имеют право участвовать в этом наследии, и именно согласованные общемировые усилия могут это гарантировать. И если говорить о НКН, то элемент отношений между разными поколениями является частью самой концепции НКН, которая в 
свою очередь является динамичной и должна передаваться от одного поколения к другому. Следовательно, ориентирование на группы для будущих поколений является важным фактором, который следует учитывать при разработке новых международно-правовых механизмов охраны НКН. Однако охрана наследия в интересах будущих поколений является лишь одной из целей охраны НКН, и это ни в коем случае не является убедительным аргументом против использования индивидуальных прав, которые можно даже рассматривать как косвенную защиту интересов будущих поколений, потому что защита в настоящем предоставляется во благо будущего.

Другой аргумент, который в целом отстаивает групповые права, но в частности применим и в обсуждениях вопросов наследия, заключается в том, что наследие отличает группу от простой совокупности ее отдельных элементов; группа существует отдельно от своих членов через общее наследие, и поэтому именно наследие делает невозможным сокращение интересов группы до интересов входящих в нее людей [28, p. 57].

Какие бы доводы ни приводились «за» или «против», в конечном счете международная система защиты прав человека остается одним из реальных средств охраны НКН, которое связано с образом жизни, составляющим часть самобытности.

Для углубления исследования в этом направлении большое значение имеет прояснение взаимосвязи культурного наследия и прав человека в условиях, когда термин «культурное наследие» не закреплен в действующих международных договорах по правам человека, и, следовательно, его нельзя обнаружить в актах, принятых международными правозащитными органами, которые могут заниматься защитой «культуры», «образа жизни» и т. п., однако не могут заниматься «наследием», ибо оно не попадает в рамки человеческого измерения и, скорее всего, относится к материальной субстанции. Иными словами, существующие международные правозащитные органы в рамках своих полномочий могут измерить культурное наследие лишь через «культуру», «образ жизни», что, конечно, не является достаточным для обеспечения всесторонней охраны «культурного наследия».
Первый правозащитный акт $\mathrm{OOH}-\mathrm{Bce}-$ общая декларация прав человека - в п. 1 ст. 27 таким образом касается этого вопроса: «каждый человек имеет право свободно участвовать в культурной жизни общества» [3]. В Международном пакте об экономических, социальных и культурных правах 1966 г. в п. 1(a) ст. 15 в этом отношении говорится: «Участвующие в настоящем Пакте государства признают право каждого человека на участие в культурной жизни» [18]. Это положение Пакта в дальнейшем получило разъяснение от Комитета ООН по экономическим, социальным и культурным правам в принятом им Замечании общего порядка № 21 в 2009 г. [21] - документе, который получил должный анализ в отечественной правовой доктрине на уровне диссертационного исследования [2].

В других международных договорах по правам человека по-разному упоминается это право: право на равное участие в культурной жизни [15, ст. 5 (e) (vi)], право на участие во всех областях социальной и культурной жизни [10, ст. 13 (c)], право на всестороннее участие в культурной и творческой жизни [12, ст. 31 (2)], право на доступ к культурной жизни и участие в ней $[14$, ст. 43 (1) (g)], право на участие наравне с другими в культурной жизни [11, ст. 30 (1)].

В этом отношении далее следует назвать три декларации, где содержатся соответствующие положения: Декларация о правах лиц, принадлежащих к национальным или этническим, религиозным и языковым меньшинствам 1992 г. (п. 1, 2 ст. 2); Декларация Организации Объединенных Наций о правах коренных народов 2007 г. (ст. 5, 8, 10-13); Декларация о праве на развитие 1986 г. (ст. 1). Конвенция МОТ № 169 о коренных народах и народах, ведущих племенной образ жизни в независимых странах 1989 г. (ст. 2, 5, 7, 8, 13-15) и Рамочная конвенция о защите национальных меньшинств 1995 г. (ст. 15) также имеют прямое отношение к этой теме.

Самым содержательным документом, разъясняющим культуру в контексте прав человека (то есть культурные права), является Замечание общего порядка № 21 Комитета по экономическим, социальным и культурным правам (КЭСКП), согласно которому культур- 
ные права представляют собой неотъемлемую часть прав человека, и их поощрение имеет важное значение для поддержания человеческого достоинства.

Касаясь нормативного содержания, Комитет по экономическим, социальным и культурным правам (КЭСКП) отмечает: право на участие в культурной жизни может быть определено в качестве одной из свобод. При этом решение человека относительно осуществления или неосуществления права на участие в культурной жизни на индивидуальной основе или совместно с другими является культурным выбором.

Еще в своем Замечании общего порядка № 17 о праве каждого на пользование защитой моральных и материальных интересов, возникающих в связи с любыми научными, литературными или художественными трудами, КЭСКП разъяснил то, каким образом культурные права могут осуществляться человеком: как отдельно взятым лицом; совместно с другими; в рамках общины как таковой. КЭСКП, опираясь на положения различных международно-правовых актов и мнения ученых, раскрывает содержание «культуры», под которой рассматривается совокупность присущих социальной группе отличительных признаков - духовных, материальных и других, которая, помимо искусства и литературы, охватывает образ жизни, «умение жить вместе», системы ценностей, традиции и верования [4]. Есть и другое понимание культуры - она представляет собой общественное явление, peзультат совместного творчества людей и воздействия, которое они оказывают друг на друга, и не ограничивается доступом к произведениям искусства и гуманитарным наукам, а является одновременно приобретением знаний, потребностью уклада жизни и необходимостью общения [19]. Можно привести еще одно определение: культура охватывает ценности, верования, языки, знания и искусства, традиции, институты и образы жизни, посредством которых личность или группа лиц выражает значение, придаваемое ею своему существованию и своему развитию [36, ст. 2 (a)]. Согласно доктринальному мнению, культура представляет собой всю совокупность материальных и интеллектуальных действий и продуктов данной социальной группы, которая отличает ее от других аналогичных групп, и систему ценностей и символов, а также комплекс практических действий, которые конкретная культурная группа воспроизводит с течением времени и которая обеспечивает отдельных лиц необходимыми ориентирами для поведения и социальных взаимоотношений в повседневной жизни [35].

Обобщая все это, КЭСКП предлагает свое понимание: культура представляет собой широкую инклюзивную концепцию, охватывающую все проявления жизни человека. Выражение «культурная жизнь» однозначным образом позволяет рассматривать культуру как исторический, динамичный и развивающийся процесс жизни с ее прошлым, настоящим и будущим.

По мнению КЭСКП, концепцию культуры необходимо рассматривать в качестве интерактивного процесса, посредством которого отдельные лица и общины, сохраняя свои отличительные черты и цели, становятся выразителями культуры человечества.

Комитет считает, что для целей осуществления п. 1 (а) ст. 15 Пакта культура охватывает, среди прочего, уклады жизни, язык, устную и письменную литературу, музыкальное и песенное творчество, неязыковое общение, систему религий или верований, ритуалы и церемонии, спорт и игры, методы производства или технологию, природную и искусственную среды, традиционную кухню, одежду и жилища, а также искусство, обычаи и традиции, посредством которых отдельные лица, группы лиц и общины выражают свои человеческие качества и тот смысл, который они придают своему существованию, а также формируют свое восприятие мира, отражающее их реакцию на те внешние силы, которые затрагивают их жизнь. Культура формирует и отражает ценности благосостояния и экономической, социальной и политической жизни отдельных лиц, групп лиц и общин. Этот перечень показывает широту составляющих элементов культурного наследия - как материального, так и нематериального характера.

КЭСКП раскрывает содержание права на «участие» и «принятие участия» в культурной жизни через три взаимосвязанных его компонента: участие в культурной жизни, доступ к культурной жизни и вклад в культурную жизнь. 
По мнению Комитета, сфера применения п. 1 (а) ст. 15 Пакта охватывает и право меньшинств и лиц, принадлежащих к меньшинствам, участвовать в культурной жизни общества, а также сохранять, пропагандировать и развивать свою собственную культуру. Это право влечет за собой обязательство государств-участников признавать, уважать и защищать культуру меньшинств в качестве важнейшего компонента самобытности самих государств. Соответственно меньшинства имеют право на свое культурное разнообразие, традиции, религию, формы образования, языки, средства массовой информации (печать, радио, телевидение, Интернет) и другие проявления их культурной самобытности и принадлежности. Меньшинства, а также лица, принадлежащие к ним, имеют право не только на свою собственную самобытность, но также и на развитие во всех сферах культурной жизни.

Комитет далее отмечает, что государствам-участникам следует принимать меры для обеспечения того, чтобы при осуществлении права на участие в культурной жизни должным образом учитывались те ценности культурной жизни, которые могут носить сугубо общинный характер или которые могут выражаться и реализовываться коренными народами только в их совокупности. Четко выраженная общинная составляющая культурной жизни коренных народов абсолютно необходима для их существования, благосостояния и всестороннего развития, она включает в себя право на территории и ресурсы, которые они традиционно занимали или иным образом использовали. К культурным ценностям и правам коренных народов, связанным с их исконными землями и их отношением к природе, следует относиться с уважением и обеспечивать их защиту в целях недопущения деградации особого уклада жизни этих народов, включая их средства к существованию, и утраты их природных ресурсов и, в конечном счете, их культурной самобытности.

Коренные народы имеют право предпринимать действия на коллективной основе для обеспечения уважения своего права сохранять, контролировать, защищать и развивать свое культурное наследие, традиционные знания и традиционные формы культурного самовыражения, а также проявления своих на- учных познаний, технологий и культур, включая людские и генетические ресурсы, семена, лекарственные препараты, знания свойств фауны и флоры, изустные традиции, литературу, орнаменты, спортивные состязания и традиционные игры, а также художественное и исполнительское искусство.

\section{Заключение}

Сказанное дает основание признать не только совместимость международной системы защиты прав человека и охраны НКН, но и необходимость использования возможностей первой для охраны последнего, а также дальнейшее расширение пределов такого взаимодействия.

\section{СПИСОК ЛИТЕРАТУРЫ}

1. Абашидзе, А. Х. Защита прав меньшинств по международному и внутригосударственному праву : монография / А. Х. Абашидзе. - М. : Права человека, 1996. $-460 \mathrm{c}$.

2. Волкова, Н. В. Защита культурных прав человека в международном праве : дис. ... канд. юрид. наук / Волкова Наталия Валерьевна. - М. : Изд-во РУДН, 2013.- 209 c.

3. Всеобщая декларация прав человека от 10 дек. 1948 г. // Резолюция ГА ООН 217 (III) «Международный пакт о правах человека» от 10 дек. 1948 г. $\mathrm{A} / \mathrm{RES} / 217(\mathrm{III})$. - Электрон. текстовые дан. - Режим доступа: http://www.un.org/ru/documents/decl_conv/ declarations/declhr. - Загл. с экрана.

4. Всеобщая декларация ЮНЕСКО о культурном разнообразии 2001 года. - Электрон. текстовые дан. - Режим доступа: http://www.un.org/ru/ documents/decl_conv/declarations/cultural_diversity. shtml (дата обращения: 01.06.2018). - Загл. с экрана.

5. Европейская хартия региональных языков или языков меньшинств 1992 г. // Серии европейских договоров. - № 148.

6. Комитет по правам человека. Замечание общего порядка № 12 - Статья 1 (право на самоопределение). Двадцать первая сессия (1984 год). - Электрон. текстовые дан. - Режим доступа: http://www. ohchr.org/RU/HRBodies/Pages/TBGeneralComments. aspx (дата обращения: 04.06.2018). - Загл. с экрана.

7. Комитет по правам человека. Замечание общего порядка № 23 - Статья 27 (документ ООН CCPR/C/21/Rev.1/Add.5). - Электрон. текстовые дан. - Режим доступа: http://www.ohchr.org/RU/ HRBodies/Pages/TBGeneralComments.aspx (дата обращения: 04.06.2018). - Загл. с экрана. 
8. Комитет по экономическим, социальным и культурным правам. Замечание общего порядка № 21 - Право каждого человека на участие в культурной жизни (документ ООНЕ/C.12/GC/21). - Электрон. текстовые дан. - Режим доступа: https:// tbinternet.ohchr.org/_layouts/treatybodyexternal/ TBSearch.aspx?Lang-ru\&TreatyID=9\&DocTypeID=11. Загл. с экрана.

9. Конвенция о защите прав человека и основных свобод 1950 г. // Собрание законодательства РФ. - 2001. - 8 янв. - № 2. - Ст. 163.

10. Конвенция о ликвидации всех форм дискриминации в отношении женщин 1979 г. // Основные международные договоры по правам человека. - Электрон. текстовые дан. - Режим доступа: http://www.un.org/ru/documents/decl_conv/ conventions/cedaw. - Загл. с экрана.

11. Конвенция о правах инвалидов 2006 г. // Новые основные международные договоры по правам человека. - Электрон. текстовые дан. - Peжим доступа: http://www.un.org/ru/documents/ decl_conv/conventions/disability. - Загл. с экрана.

12. Конвенция о правах ребенка 1989 г. // Основные международные договоры по правам человека. - Электрон. текстовые дан. - Режим доступа: http://www.un.org/ru/documents/decl_conv/ conventions/childcon.shtml. - Загл. с экрана.

13. Конвенция об охране нематериального культурного наследия 2003 г. - Электрон. текстовые дан. - Режим доступа: http://www.un.org/ru/ documents/decl_conv/conventions/cultural_ heritage_conv.shtml (дата обращения: 01.06.2018). Загл. с экрана.

14. Международная конвенция о защите прав всех трудящихся-мигрантов и членов их семей 1990 г. // Основные международные договоры по правам человека. - Электрон. текстовые дан. - Режим доступа: http://www.un.org/ru/documents/decl_conv/ conventions/migrant4.shtml. - Загл. с экрана.

15. Международная конвенция о ликвидации всех форм расовой дискриминации 1965 г. // Основные международные договоры по правам человека. - Электрон. текстовые дан. - Режим доступа: http://www.un.org/ru/documents/decl_conv/ conventions/raceconv. - Загл. с экрана.

16. Международный пакт о гражданских и политических правах 1966 г. // Ведомости Верховного Совета СССР. - 1976. - 28 апр. - № 17. - Ст. 291.

17. Права и свободы человека. Основополагающие международные акты : сб. / сост. А. Х. Абашидзе, Н. Д. Эриашвили. - М. : ЮНИТИ-ДАНА : Закон и право, 2018. - 952 с.

18. Резолюция Генеральной Ассамблеи $\mathrm{OOH}$ A/RES/2200(XXI) «Международный пакт об экономических, социальных и культурных правах, Международный пакт о гражданских и политических правах и Факультативный протокол к Международному пакту о гражданских и политических правах» от 16 дек. 1966 г. - Электрон. текстовые дан. - Режим доступа: http://undocs.org/ru/A/RES/2200(XXI). Загл. с экрана.

19. Рекомендация об участии и вкладе народных масс в культурную жизнь 1976 г. - Электрон. текстовые дан. - Режим доступа: http://docs.cntd.ru/ document/901756981 (дата обращения: 01.06.2018). Загл. с экрана.

20. Blake, J. Commentary on the UNESCO 2003 Convention on the Safeguarding of the Intangible Cultural Heritage / J. Blake. - Leicester : Institute for Art and Law, 2006. - 180 p.

21. Committee on Economic, Social and Cultural Rights, General Comment 21: Right of everyone to take part in cultural life (art 15, para 1(a), of the International Covenant on Economic, Social and Cultural Rights), 21 December 2009 // UN Doc E/C.12/GC/21. Electronic text data. - Mode of access: https:// www.uio.no/studier/emner/jus/jus/JUS5710/h14/ undervisningsmateriale/cescr_cultural-life.pdf. - Title from screen.

22. Dinstein, Y. Collective Human Rights of Peoples and Minorities / Y. Dinstein // International \& Comparative Law Quarterly. - 1976. - Vol. 25. Iss. 1.P. $102-120$.

23. Gillman, D. The Idea of Cultural Heritage /D. Gillman. - Cambridge : Cambridge University Press, Institute for Art and Law, 2006. - 218 p.

24. Hartney, M. Some Confusions Concerning Collective Rights / M. Hartney// Canadian Journal of Law and Jurisprudence. - 1991. - Vol. 4. No. 2. - P. 293-314.

25. Human Rights Committee, Communication No 547/1993, Apirana Mahuika et al. v. New Zealand // UN Doc CCPR/C/70/D/547. - Electronic text data. Mode of access: https://www.uio.no/studier/emner/ jus/jus/JUS5710/h13/undervisningsmateriale/apirana_ mahuika_new_zealand.pdf. - Title from screen.

26. Inter-American Court of Human Rights. Case of Lopez-Alvarez v. Honduras. Merits, Reparations, and Costs. Judgment of 1 February 2006. Series C. No 141. Electronic text data. - Mode of access: http://www. corteidh.or.cr/docs/casos/articulos/seriec_141_ing.pdf (date of access: 01.06.2018). - Title from screen.

27. Johnston, D. M. Native Rights as Collective Rights: A Question of Group Self-Preservation / D. M. Johnston // Canadian Journal of Law and Jurisprudence. - 1989. - Vol. 2. No. 1. - P. 179-201.

28. Jovanovic, M. A. Recognizing Minority Identities Through Collective Rights / M. A. Jovanovic // Human Rights Quarterly. - 2005. - Vol. 27. No. 2. P. 625-651.

29. Kukathas, Ch. Are There Any Cultural Rights? / Ch. Kukathas // Political Theory. - 1992. - Vol. 20. No. 1.-P. 105-139. 
30. Kymlicka, W. Multicultural States and Intercultural Citizens/W. Kymlicka//Theory and Research in Education. - 2003. - Vol. 1. No. 2. -P. 147-169.

31. Lixinski, L. Intangible Cultural Heritage in International Law / L. Lixinski. - Oxford : Oxford University Press, 2013. - 274 p.

32. Lopez Ostra v. Spain (Application No 16798/ 90), judgment of 9 December 1994. - Electronic text data. - Mode of access: https://hudoc.echr.coe.int/ eng $? \mathrm{i}=001-57905 \#\{\% 22$ itemid $\% 22:[\% 22001$ $57905 \% 22]\}$ (date of access: 01.06.2018). - Title from screen.

33. Lowenthal, D. The Heritage Crusade and the Spoils of History / D. Lowenthal. - Cambridge : Cambridge University Press, 1998. -358 p.

34. Pentassuglia, G. Minority Groups and Judicial Discourse in International Law: A Comparative Perspective / G. Pentassuglia. - Leiden : Martinus Nijhoff, 2009. $-278 \mathrm{p}$.

35. Stavenhagen, R. Cultural Rights: A social science perspective / R. Stavenhagen // Cultural Rights and Wrongs: A collection of essays in commemoration of the 50th anniversary of the Universal Declaration of Human Rights / H. Niec (ed.). - Paris ; Leicester : UNESCO Publishing and Institute of Art and Law, 1999. - P. 29-52.

36. The Friborg Declaration on Cultural Rights 2007. - Electronic text data. - Mode of access: http:// hrlibrary.umn.edu/instree/Fribourg\%20Declaration.pdf (date of access: 01.06.2018). - Title from screen.

37. Weisbrod, C. Emblems of Pluralism: Cultural Differences and the State / C. Weisbrod. - Princeton : Princeton University Press, 2002. -232 p.

38. Ziegler, K. S. Cultural Heritage and Human Rights. Social Sciences Resource Network / K. S. Ziegler. Electronic text data. - Mode of access: http://ssrn.com/ abstract $=1002620$ (date of access: 01.06 .2018 ). - Title from screen.

\section{REFERENCES}

1. Abashidze A.Kh. Zashchita prav menshinstv po mezhdunarodnomu $i$ vnutrigosudarstvennomu pravu [Protection of Minority Rights in International and National Law]. Moscow, Prava cheloveka Publ., $1996.460 \mathrm{p}$.

2. Volkova N.V. Zashchita kulturnykh prav cheloveka $v$ mezhdunarodnom prave: dis. ... kand. yurid. nauk [Protection of Cultural Human Rights in International Law. Cand. jurid. sci. diss.]. Moscow, RUDN Publ., 2013. 209 p.

3. Vseobshchaya deklaratsiya prav cheloveka ot 10 dek. 1948 g. [Universal Declaration of Human Rights of 10 December 1948]. Rezolyutsiya GA OON 217 (III) "Mezhdunarodnyy pakt o pravakh cheloveka» ot 10 dek. 1948 g. A/RES/217(III)
[Resolution of UN General Assembly 217 (III) 'Internation Pact on Human Rights' of 10 December 1948 A/RES/217(III)].

4. Vseobshchaya deklaratsiya YUNESKO o kulturnom raznoobrazii 2001 goda [UNESCO Universal Declaration on Cultural Diversity, 2001]. URL: http://www.un.org/ru/documents/decl_conv/ declarations/cultural_diversity.shtml (accessed 1 June 2018).

5. Evropeyskaya khartiya regionalnykh yazykov ili yazykov menshinstv $1992 \mathrm{~g}$. [European Charter for Regional or Minority Languages, 1992]. Serii evropeyskikh dogovorov [European Treaty Series], no. 148.

6. Komitet po pravam cheloveka. Zamechanie obshchego poryadka № 12 - Statya 1 (pravo na samoopredelenie). Dvadtsat pervaya sessiya (1984 god) [Human Rights Committee. General Comment No. 12 -Article 1 (Right to Self-Determination). Twenty-First Session (1984)]. URL: http://www. ohchr.org/RU/HRBodies/Pages/TBGeneralComments. aspx (accessed 1 June 2018).

7. Komitet po pravam cheloveka. Zamechanie obshchego poryadka № 23 - Statya 27 (dokument OON CCPR/C/21/Rev.1/Add.5) [Human Rights Committee. General Comment No. 23 -Article 27 (UN Document CCPR/C/21/Rev.1/Add.5)]. URL: http:// www.ohchr.org/RU/HRBodies/Pages/TBGeneral Comments.aspx (accessed 1 June 2018).

8. Komitet po ekonomicheskim, sotsialnym $i$ kulturnym pravam. Zamechanie obshchego poryadka № 21 - Pravo kazhdogo cheloveka na uchastie $v$ kulturnoy zhizni (dokument OON E/C.12/GC/21) [Committee on Economic, Social and Cultural Rights. General Comment No. 21 - The Right of Everyone to Take Part in Cultural Life (UN Document E/C.12/GC/ 21)]. URL: https://tbinternet.ohchr.org/_layouts/ treatybodyexternal/TBSearch.aspx? Lang=ru\& TreatyID $=9 \&$ DocTypeID $=11$.

9. Konventsiya o zashchite prav cheloveka $\mathrm{i}$ osnovnykh svobod $1950 \mathrm{~g}$. [Convention for the Protection of Human Rights and Fundamental Freedoms, 1950]. Sobranie zakonodatelstva $R F$ [Collected Legislation of the Russian Federation], 2001, no. 2, art. 163. URL: https://www.echr.coe.int/Documents/ Convention_ENG.pdf(accessed 1 June 2018).

10. Konventsiya o likvidatsii vsekh form diskriminatsii v otnoshenii zhenshchin 1979 g. [Convention on the Elimination of All Forms of Discrimination against Women, 1979]. Osnovnye mezhdunarodnye dogovory po pravam cheloveka [Core International Treaties on Human Rights]. URL: http://www.un.org/ru/documents/decl_conv/ conventions/cedaw.

11. Konventsiya o pravakh invalidov 2006 g. [Convention on the Rights of Persons with Disabilities, 
2006]. Novye osnovnye mezhdunarodnye dogovory po pravam cheloveka [New Core International Treaties on Human Rights]. URL: http://www.un.org/ru/ documents/decl conv/conventions/disability.

12. Konventsiya o pravakh rebenka $1989 \mathrm{~g}$. [Convention on Children's Rights 1989]. Osnovnye mezhdunarodnye dogovory po pravam cheloveka [Core International Treaties on Human Rights]. URL: http://www.un.org/ru/documents/decl conv/ conventions/childcon.shtml.

13. Konventsiya ob okhrane nematerialnogo kulturnogo naslediya $2003 \mathrm{~g}$. [The UNESCO Convention for the Safeguarding of Intangible Cultural Heritage, 2003]. URL: http://www.un.org/ru/ documents/decl_conv/conventions/cultural heritage conv.shtml (accessed 1 June 2018).

14. Mezhdunarodnaya konventsiya o zashchite prav vsekh trudyashchikhsya-migrantov i chlenov ikh semey 1990 g. [International Convention on the Protection of the Rights of All Migrant Workers and Members of Their Families, 1990]. Osnovnye mezhdunarodnye dogovory po pravam cheloveka [Core International Treaties on Human Rights]. URL: http://www.un.org/ru/documents/decl_conv/ conventions/migrant4.shtml.

15. Mezhdunarodnaya konventsiya o likvidatsii vsekh form rasovoy diskriminatsii $1965 \mathrm{~g}$. [International Convention on the Elimination of All Forms of Racial Discrimination, 1965]. Osnovnye mezhdunarodnye dogovory po pravam cheloveka [Core International Treaties on Human Rights]. URL: http:/www.un.org/ ru/documents/decl_conv/conventions/raceconv.

16. Mezhdunarodnyy pakt o grazhdanskikh i politicheskikh pravakh $1966 \mathrm{~g}$. [International Covenant on Civil and Political Rights 1966]. Vedomosti Verkhovnogo Soveta SSSR, 1976, no. 17 (Apr. 28), art. 291.

17. Abashidze A.Kh., Eriashvili N.D., eds. Prava i svobody cheloveka. Osnovopolagayushchie mezhdunarodnye akty [Human Rights and Freedoms. Core International Acts]. Moscow, YUNITI-DANA; Zakon i pravo Publ, 2018. 952 p.

18. Rezolyutsiya Generalnoy Assamblei OON A/ RES/2200(XXI) «Mezhdunarodnyy pakt ob ekonomicheskikh, sotsialnykh i kulturnykh pravakh, Mezhdunarodnyy pakt o grazhdanskikh $i$ politicheskikh pravakh i Fakultativnyy protokol $k$ Mezhdunarodnomu paktu o grazhdanskikh $i$ politicheskikh pravakh» ot 16 dek. 1966 g. [UN General Assembly Resolution A/RES/2200 (XXI) 'International Covenant on Economic, Social and Cultural Rights, International Covenant on Civil and Political Rights and Optional Protocol to the International Covenant on Civil and Political Rights" of 16 December 1966]. URL: http://undocs.org/ru/A/ RES/2200(XXI)
19. Rekomendatsiya ob uchastii $i$ vklade narodnykh mass $v$ kulturnuyu zhizn $1976 \mathrm{~g}$. [The UNESCO Recommendation on People Participation in Cultural Life and Their Contribution to It, 1976]. URL: http://docs.cntd.ru/document/901756981 (accessed 1 June 2018).

20. Blake J. Commentary on the UNESCO 2003 Convention on the Safeguarding of the Intangible Cultural Heritage. Leicester, Institute for Art and Law, 2006. 180 p.

21. Committee on Economic, Social and Cultural Rights, General Comment 21: Right of everyone to take part in cultural life (art 15, para 1(a), of the International Covenant on Economic, Social and Cultural Rights), 21 December 2009. UN Doc E/C.12/GC/21. URL: https://www.uio.no/studier/emner/jus/jus/JUS5710/ h14/undervisningsmateriale/cescr_cultural-life.pdf.

22. Dinstein Y. Collective Human Rights of Peoples and Minorities. International \& Comparative Law Quarterly, 1976, vol. 25, iss. 1, pp. 102-120.

23. Gillman D. The Idea of Cultural Heritage. Cambridge, Cambridge University Press, Institute for Art and Law, 2006. 218 p.

24. Hartney M. Some Confusions Concerning Collective Rights. Canadian Journal of Law and Jurisprudence, 1991, vol. 4, no. 2, pp. 293-314.

25. Human Rights Committee, Communication No 547/1993, Apirana Mahuika et al. v. New Zealand. UN Doc CCPR/C/70/D/547. URL: https://www. uio.no/studier/emner/jus/jus/JUS5710/h13/ undervisningsmateriale/apirana_mahuika_new_ zealand.pdf.

26. Inter-American Court of Human Rights. Case of Lopez-Alvarez v. Honduras. Merits, Reparations, and Costs. Judgment of 1 February 2006. Series C. No 141. URL: http:/www.corteidh.or.cr/docs/casos/ articulos/seriec_141_ing.pdf(accessed 1 June 2018).

27. Johnston D.M. Native Rights as Collective Rights: A Question of Group Self-Preservation. Canadian Journal of Law and Jurisprudence, 1989, vol. 2, no. 1, pp. 179-201.

28. Jovanovic M.A. Recognizing Minority Identities Through Collective Rights. Human Rights Quarterly, 2005, vol. 27, no. 2, pp. 625-651.

29. Kukathas $\mathrm{Ch}$. Are There Any Cultural Rights? Political Theory, 1992, vol. 20, no. 1, pp. 105-139.

30. Kymlicka W. Multicultural States and Intercultural Citizens. Theory and Research in Education, 2003, vol. 1, no. 2, pp. 147-169.

31. Lixinski L. Intangible Cultural Heritage in International Law. Oxford, Oxford University Press, 2013. 274 p.

32. Lopez Ostra v. Spain (Application No 16798/ 90), judgment of 9 December 1994. URL: https:// hudoc.echr.coe.int/eng? $\mathrm{i}=001-57905 \#\{\% 22$ itemid $\% 22$ : [\%22001-57905\%22]\} (accessed 1 June 2018). 
Гюнай Видади кызы Алиева. Возможности и пределы охраны нематериального культурного наследия

33. Lowenthal D. The Heritage Crusade and the Spoils of History. Cambridge, Cambridge University Press, 1998. 358 p.

34. Pentassuglia G. Minority Groups and Judicial Discourse in International Law: A Comparative Perspective. Leiden, Martinus Nijhoff, 2009. $278 \mathrm{p}$.

35. Stavenhagen R. Cultural Rights: A social science perspective. Niec H., ed. Cultural Rights and Wrongs: A collection of essays in commemoration of the 50th anniversary of the Universal Declaration of
Human Rights. Paris; Leicester, UNESCO Publishing and Institute of Art and Law, 1999, pp. 29-52.

36. The Friborg Declaration on Cultural Rights 2007. URL: http://hrlibrary.umn.edu/instree/ Fribourg\%20Declaration.pdf(accessed 1 June 2018).

37. Weisbrod C. Emblems of Pluralism: Cultural Differences and the State. Princeton, Princeton University Press, 2002. 232 p.

38. Ziegler K.S. Cultural Heritage and Human Rights. Social Sciences Resource Network. URL: http:/ /ssrn.com/abstract=1002620 (accessed 1 June 2018).

\section{Information about the Author}

Gunay Vidadi qizi Aliyeva, Postgraduate Student, Department of International Law, Peoples' Friendship University of Russia, Miklukho-Maklaya St., 6, 117198 Moscow, Russian Federation, gunayg17@hotmail.com.

\section{Информация об авторе}

Гюнай Видади кызы Алиева, аспирант кафедры международного права, Российский университет дружбы народов, ул. Миклухо-Маклая, 6, 117198 г. Москва, Российская Федерация, gunayg17@hotmail.com. 